\title{
Arbejdsliv i Norden
}

\section{Udfordringer og forslag}

/ Poul Nielson

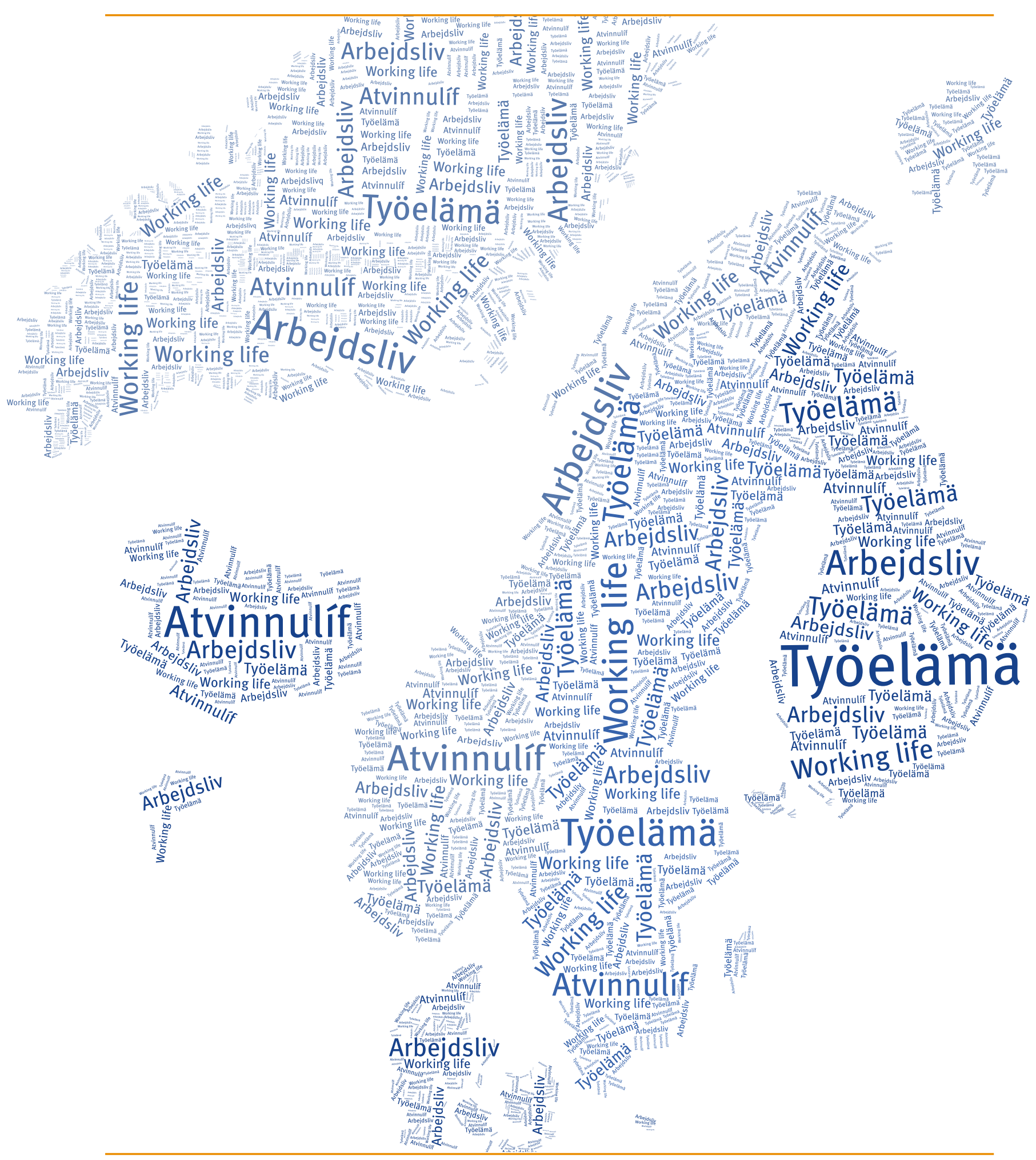



De nordiske arbejdsmarkedsministre i Nordisk Ministerråd besluttede 20. november 2014 at gennemføre en strategisk gennemlysning af det nordiske samarbejde på arbejdslivsområdet. Rapporten skulle indeholde 10-15 konkrete handlingsorienterede forslag til at udvikle det nordiske samarbejde på arbejdslivsområdet de næste 5-10 år. I april 2015 sagde jeg ja til at påtage mig denne opgave.

Siden da har jeg gennemført omfattende konsultationer med ministre, parlamentarikere, embedsfolk, forskere, repræsentanter for arbejdsgivere og fagbevægelse overalt i Norden samt møder i EU-Kommissionen, Europa-Parlamentet, europæiske tænketanke, ILO og OECD. I løbet af arbejdet med rapporten har jeg gennemført over 100 samtaler og bl.a. været igennem referater af flere års ministermøder. Ved skrivningen af rapporten har jeg valgt at undlade konkrete referencer - også fordi dette harmonerer bedre med, at jeg alene er ansvarlig for rapportens indhold.

Jeg har mødt stor interesse og hjælpsomhed fra alle sider i dette arbejde, hvilket har været en bekræftelse af betimeligheden af beslutningen om at gennemføre denne analyse. Jeg vil gerne takke alle de mange, der har bidraget med deres indsigt, erfaringer og synspunkter i processen. En særlig tak til Nordisk Ministerråds sekretariat og specielt til seniorrådgiver Ulf Andreasson, som både har været en god ven på de mange rejser og en inspirerende og indsigtsfuld sparringspartner i processen. 


\section{Arbejdsliv i Norden - Udfordringer og forslag}

ISBN 978-92-893-4574-3 (PRINT)

ISBN 978-92-893-4575-0 (PDF)

http://dx.doi.org/10.6027/ANP2016-732

ANP 2016:732

C N Nordisk Ministerråd 2016

Layout: Jette Koefoed/Erling Lynder

Omslagsfoto: Erling Lynder

Foto: s. 8, Yadid Levy; s. 22, 33, ImageSelect;

s. 26, Karin Beate Nøsterud

Tryk: Rosendahls

Oplag: 400

Skrift: Meta LF

Papir: Munken Polar

Printed in Denmark

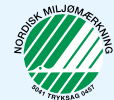

www.norden.org/nordpub

\section{Det nordiske samarbejde}

Det nordiske samarbejde er en af verdens mest omfattende regionale samarbejdsformer. Samarbejdet omfatter Danmark, Finland, Island, Norge og Sverige samt Færøerne, Grønland og Åland.

Det nordiske samarbejde er både politisk, økonomisk og kulturelt forankret, og er en vigtig medspiller i det europæiske og internationale samarbejde. Det nordiske fællesskab arbejder for et stærkt Norden i et stærkt Europa.

Det nordiske samarbejde ønsker at styrke nordiske og regionale interesser og værdier i en global omverden. Fælles værdier landene imellem er med til at styrke Nordens position som en af verdens mest innovative og konkurrencedygtige regioner.

\section{Nordisk Ministerråd}

Ved Stranden 18

1061 København $\mathrm{K}$

Telefon (+45) 33960200

www.norden.org 


\section{Arbejdsliv i Norden}

Udfordringer og forslag

$\begin{array}{ll}\text { Introduktion } & 6\end{array}$

Substantielle, fællesnordiske emner 9

Grænsehindringer 9

$\begin{array}{ll}\text { Migrationspresset } & 10\end{array}$

$\begin{array}{ll}\text { Statistik } & 11\end{array}$

$\begin{array}{ll}\text { Arbejdsmiljø } & 12\end{array}$

$\begin{array}{lr}\text { Ligestilling } & 14\end{array}$

$\begin{array}{ll}\text { Strukturændringer og organisationernes repræsentativitet } & 15\end{array}$

$\begin{array}{ll}\text { Uddannelse } & 18\end{array}$

$\begin{array}{ll}\text { Vestnorden } & 20\end{array}$

$\begin{array}{ll}\text { Institutionelle emner } & 23\end{array}$

$\begin{array}{lr}\text { Ministerrådet for Arbejdsliv (MR-A) } & 24\end{array}$

$\begin{array}{ll}\text { Norden i EU } & 27\end{array}$

$\begin{array}{ll}\text { Beskrivelse } & 27\end{array}$

Hvad kan Norden gøre? $\quad 30$

$\begin{array}{ll}\text { Norden i verden } & 33\end{array}$

Den Internationale Arbejdsorganisation (ILO) 33

$\begin{array}{ll}\text { OECD } & 34\end{array}$ 


\section{Introduktion}

Uanset en række forskelle fra land til land i Norden i henseende til struktur og politik på arbejdsmarkedsområdet i bred forstand, så er der en kerne af fælles arbejdsformer, normer og værdier, som tilsammen definerer karakteren af arbejdslivet og arbejdsmarkedspolitikken i de nordiske lande, som gør det meningsfuldt at tale om "den nordiske model”, og som på væsentlige punkter skiller sig ud fra forholdene på arbejdsmarkedet $\mathrm{i}$ de fleste andre lande - både i Europa og i resten af verden.

Vi har over tid i Norden udviklet en forhandlingskultur mellem arbejdsgivere og lønmodtagere bygget på en forståelse for værdien af et velorganiseret arbejdsmarked, og hvor staten og lovgivningsmagten spiller en tilbagetrukket og understøttende rolle. En set $\mathrm{i}$ international sammenligning høj grad af organisering både på lønmodtagersiden og arbejdsgiversiden har underbygget såvel legitimiteten som funktionsevnen af "modellen". Man kan sige, at der er opbygget en "kompromiskompetence", som står i kontrast til forholdet mellem de to sider på arbejdsmarkedet mange andre steder.

Det er væsentligt at forstå, at denne udvikling ikke er sket i et samfundsmæssigt eller politisk vacuum, men i en historisk sammenhæng med opbygningen af vore nordiske velfærdssamfund baseret på en anerkendelse af fællesskabets sociale og medmenneskelige ansvar. Og lige som der på arbejdsmarkedet er en forskel mellem Norden og mange andre lande, så skiller de nordiske lande sig også ud ved at være præget af mindre ulighed og større social tryghed end de fleste andre lande. Også den politiske forhandlingskultur, hvor proportionalvalg har understøttet en vis pragmatisme og nødvendighed af kompromiser, rimer med udviklingen på arbejdsmarkedet. Det hører med i billedet, at hele denne udvikling har ført til velstående og velfungerende samfund. Når man rundt om i verden refererer til "den nordiske model", tænkes der således ikke kun på forholdene på arbejdsmarkedet, men på karakteren af vore samfund som helhed. Denne rapports tema er ikke det generelt samfundspolitiske, men arbejdslivet og samarbejdet om det i Norden. Men der er mange aspekter af arbejdslivet, der ikke klart kan afgrænses fra andre områder (f.eks. uddannelse, sundhed, migration). Det demokratiske velfærdssamfund og "den nordiske arbejdsmarkedsmodel" er hinandens forudsætninger.

Konventionen om et fælles arbejdsmarked i Norden i 1954 var en progressiv be- 
slutning, som har bidraget til vækst og beskæftigelse i vore lande. Men i de sidste 20 år har der stort set ikke været en parallel opfølgning i form af en systematisk indsats for harmonisering og integration $i$ Norden på arbejdslivets forskellige områder. Der er derfor grund til at afsøge muligheder for, hvor fælles løsninger kan bevare og styrke de værdier, vi er fælles om, og som kan være et svar på de udfordringer, vi i dag står over for. Det er ikke svært at få øje på udfordringerne: Globaliseringen og teknologiudviklingen, strukturændringerne på arbejdsmarkedet, vanskeligheden ved at opretholde høje organisationsprocenter, flygtningestrømmen, migrationspresset globalt og bivirkningerne af den frie bevægelighed for foretagender og lønmodtagere i Europa. Processen i EU med opbygningen af en arbejdsmarkedspolitik, der fra direktiv til direktiv - og fra dom til dom - tilstræber at skabe fælles regler til sikring af Traktatens grundprincipper og til udmøntning og beskyttelse af rettighederne på begge sider af arbejdsmarkedet, har i praksis betydet, at de nordiske lande i vidt omfang er blevet placeret i en reaktiv position, hvor implementeringen af direktiver og efterlevelse af domstolenes kendelser fylder mere end en proaktiv indsats på at formulere en fælles politik og søge indflydelse på selve substansen i den europæiske proces. Ønsket om at skabe en mere aktivt markeret fælles nordisk indsats på arbejdslivsområdet skal imidlertid ikke kun ses som en defensiv bestræbelse for at fastholde vore principper og værdier. Vi har god grund til også i fællesskab at reagere positivt på den interesse, der fra mange sider vises "den nordiske model". En aktiv branding af vore arbejdsformer, normer og værdier i arbejdslivet er ganske enkelt også et godt tilbud til omverdenen.

Det skal for klarheds skyld bemærkes, at det i udarbejdelsen af rapporten har været et bevidst valg ikke at inddrage den offentlige sektors særlige forhold.

Udfordringerne og mulighederne for at identificere nye ideer, der kan styrke samarbejdet i Norden på arbejdslivsområdet kan opdeles i fire kategorier:

- Substantielle, fællesnordiske emner

- Institutionelle emner i det nordiske samarbejde

- Det nordiske arbejdsmarked

- EU. Norden i verden. 


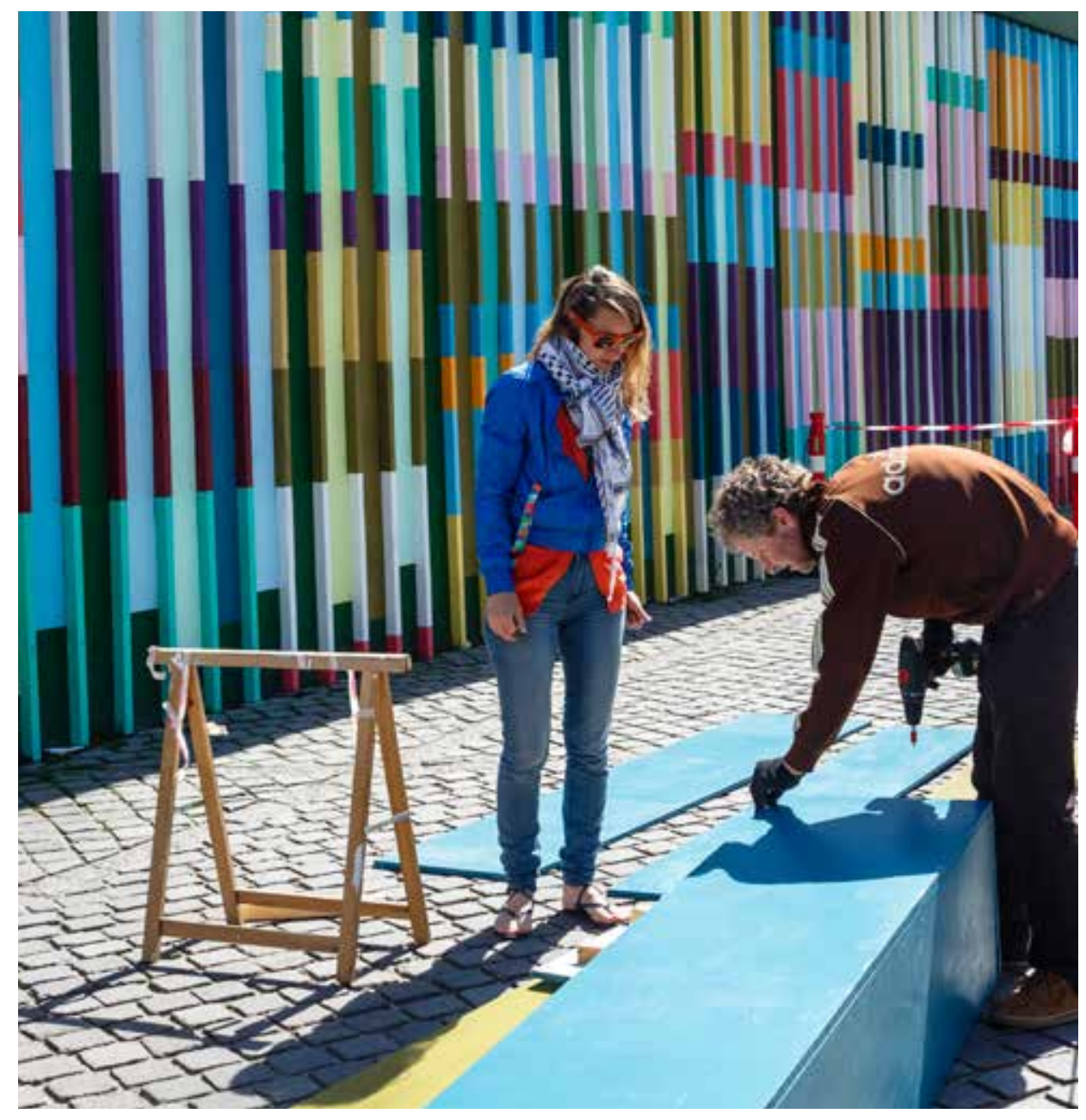




\section{Substantielle, fællesnordiske emner}

\section{Grænsehindringer}

Arbejdet med at fjerne forskellige ulemper og hindringer i den frie bevægelse på tværs af grænserne er en vigtig del af bestræbelsen på at virkeliggøre det fælles arbejdsmarked i Norden. Arbejdsformen i Grænsehindringsrådet er en meningsfuld og direkte måde at presse på for at løse de forskellige problemer. For blot at nævne nogle: Godkendelse af autorisationer (f.eks. elinstallatører) såvel som en bedre kontrol og opfølgning i de andre lande i de tilfælde, hvor myndigheden i et land har frataget f.eks. en læges autorisation. Problematiske samspil mellem dagpengeregler og A-kasser. Uddannelsesstøtte og beskatningsforhold. Vedrørende tekniske standarder i byggeriet påpeger Grænsehindringsrådet år efter år, at det forhold, at mange af disse bestemmes af brancheorganisationerne i de enkelte lande, gør det svært at angribe problemet gennem lovgivning!

\begin{abstract}
Alle disse hindringer er reelle og ofte betydelige gener for de berørte borgere og virksomheder især i grænseregionerne uanset, at problemerne ikke på nationalt plan vejer særlig tungt. En grund til trægheden i at imødekomme ønsket om ændringer er, at det i mange tilfælde vil kræve dybtgående og principielle ændringer i f.eks. skattesystemer for at kunne eliminere det, der er et problem for relativt få mennesker. Det kunne i sådanne tilfælde være en idé at skabe en slags virtuel, grænserelevant jura, hvor en klart afgrænset kreds af berørte borgere fik defineret en slags gennemsnitsløsninger, som løftede dem ud af dilemmaet i forhold til de store systemer. Hvis ikke systemerne kan harmoniseres, og hvis man alligevel vil fjerne grænsehindringerne, må man skræddersy nogle særligt forhandlede og afgrænsede grænseløsninger. Til illustration kunne dette forslag for $\emptyset$ resundsregionens vedkommende kaldes et "juridisk virtuelt Hven".
\end{abstract}

Forslag 1: $\quad$ Grænsehindringsrådets arbejde suppleres med en undersøgelse af muligheden for at skabe løsninger på tværs af de etablerede systemer omfattende afgrænsede og specifikt definerede personkredse. En sådan undersøgelse må nødvendigvis være en fællesnordisk opgave med afsæt $i$ en eksplicit støtte fra regeringerne. 


\section{Migrationspresset}

Det vil virke totalt virkelighedsfornægtende at tale om grænsehindringer i Norden uden at inddrage presset på vore arbejdsmarkeder i medfør at flygtningestrømmen og det globale migrationspres. Proportionerne er på kort tid blevet sådan, at denne udfordring har lagt sig oven i alle de øvrige i forvejen identificerede problemfelter som bl.a. arbejdsmarkedsuddannelser, ungdomsarbejdsløshed, social dumping, svækkelse af organisationsgraden og udfordringen om at imødegå tendensen til øget ulighed.

Konsekvensen af dette er, at det politiske arbejdsfelt, der har været fokuseret på arbejdsmarkedet og arbejdslivet mere generelt, er blevet løftet op i toppen af den tunge, almene politiske dagsorden. På kort sigt giver det ikke nogen mening at tale om arbejdsmarkedspolitik as usual. Det bliver derfor nødvendigt at konfrontere de nordiske landes regeringer med spørgsmålet om, i hvilket omfang man vil samarbejde om at fastholde grundprincipperne i det fælles nordiske arbejdsmarked og de værdier, der er kernen i "modellen" - uanset de ekstra udfordringer, som flygtninge- og migrationspresset stiller os over for? Dette spørgsmål må stilles i relation til såvel håndteringen på kort sigt af indvandringen som til betydningen på længere sigt af dette for arbejdslivet i Norden.

Set udefra har de nordiske landes regeringers håndtering af problemet ikke styrket billedet af Norden som en region, der skiller sig ud med et tæt og velkoordineret samarbejde. Man kan sige, at fraværet af en effektivt administreret, fælles europæisk flygtninge- og indvandrerpolitik at forholde sig til ikke gør dette nemmere. De nordiske lande har som gruppe betragtet heller ikke hidtil bidraget til at muliggøre formuleringen af en sådan politik.

De principielle, overordnede aspekter af flygtninge- og indvandringspolitikken ligger uden for rækkevidden af denne rapport. Men tilbage står, at kataloget over udfordringer for arbejdslivet i Norden egentlig er uændret - blot nu med et tungere lag af problemer hen over det hele. Vores fælles vilje og evne til at møde udfordringerne med udgangspunkt i de værdier, der er kernen i "den nordiske model”, vil være afgørende for, om indvandringen også kan ende med at blive en positiv ressource i vore samfund. For ligestillingsspørgsmålet og specielt for indvandrerkvindernes vedkommende er det afgørende, at disse værdier holdes i hævd.

Alt tyder på, at en hurtig deltagelse i arbejdslivet - kombineret med et element af sprogundervisning m.m. - er en bedre fremgangsmåde end at bruge flere år på forberedende aktiviteter. Learning by doing er et godt motto for integrationsbestræbelsen. Erfaringsudveksling er en væsentlig, gennemgående kvalitet i det nordiske samarbejde og vil også være det i forbindelse med håndteringen af migrationspresset. Men der er brug for mere end det. En systematisk fælles indsats er nødvendig. I lys af den afgørende betydning deltagelse $i$ arbejdslivet har for integrationsindsatsen, bør MR-A gå forrest i dette, også selvom det kræver en sektormæssigt tværgående indsats.

Forslag 2: $\quad$ Der oprettes en særlig arbejdsgruppe under Ministerrådet, som løbende skal samle opdaterede situationsrapporter, gennemføre konsoliderede, fælles analyser (et fortløbende nordisk peer review) og fremkomme med forslag og anbefalinger til initiativer. En sådan arbejdsgruppe skal bidrage til at skabe grundlaget for en mere substantiel og handlingsorienteret fællesnordisk politisk indsats i overensstemmelse med vore grundlæggende værdier. 


\section{Statistik}

Det er fra mange sider i løbet af samtalerne rundt i Norden blevet efterlyst, at der gøres en mere seriøs indsats på at forbedre produktionen af statistik i bred forstand af betydning for arbejdslivet. Der er mange områder, hvor inkompatibilitet skaber problemer, ikke blot i forskning og uddannelse om arbejdsmarkedsforhold, men også for det praktiske samarbejde. Som et klart eksempel på dette kan nævnes, at det ikke har været muligt at producere en fælles, éntydigt defineret statistik til belysning af antallet af udstationeret arbejdskraft i Norden. Grænsehindringsrådet peger også på behovet for bedre fælles statistik.

Der er naturligvis i mange tilfælde gode grunde til, at statistiske definitioner og metoder afspejler særlige lovgivningsmæssige og praktiske forhold, og mange af disse problemer kan ikke afgrænses til arbejdsmarkedsstatistik i snæver forstand. Men de statistiske kompatibilitetsproblemer er så reelle, at de i sig selv besværliggør en smidig erfaringsudveksling og en fælles politikudvikling. Det forhold, at f.eks. Eurostat, OECD og ILO naturligvis har endnu større udfordringer end de nordiske lande med at skabe forståelige og direkte sammenlignelige definitioner og beskrivelser af arbejdsløshedstal, arbejdsulykker, arbejdsmiljøforhold, ligestilling, funktionshindredes forhold m.m. gør ikke opgaven nemmere.

Der er allerede iværksat en række initiativer på dette område, men denne sag er et oplagt arbejdsfelt, hvor en fælles nordisk indsats ikke kun vil være nyttig for udviklingen af det nordiske samarbejde, men også være en aktivitet, der demonstrerer de nordiske landes kapacitet til at bidrage med ideer og løsninger, der vil blive hilst velkommen internationalt. Selvom fokus skal være på arbejdsmarkedsstatistik, vil et initiativ af denne art fra de nordiske lande kunne stimulere et bedre samarbejde mere bredt i bestræbelsen på at forbedre det internationale samfunds statistik.

Forslag 3: De nordiske regeringer nedsætter en styregruppe med inddragelse af relevant ekspertise fra myndigheder, universiteter og parterne på arbejdsmarkedet til i første omgang at opstille et slags problemkatalog over mangler og tekniske kritikpunkter, derefter opstille en prioriteret liste over disse og fremkomme med forslag til skabelsen af bedre kvalitet og kompatibilitet i arbejdsmarkedsstatistikken. Endelig skal dette arbejde knytte an til arbejdet i ILO, OECD og EU med at forbedre produktionen af statistik. Koordinationen og støtten til styregruppens arbejde varetages af Nordisk Ministerråds sekretariat. 


\section{Arbejdsmiljø}

Arbejdsmiljø tegner til at blive et helt centralt problemfelt i fremtidens arbejdsliv og også noget, der vil stille større krav til samspillet mellem parterne på arbejdsmarkedet og staten. Højere pensionsalder, accelereret teknologiudvikling og global konkurrence vil nødvendiggøre en opprioritering af indsatsen for et godt arbejdsmiljø, hvis livskvaliteten i arbejdslivet skal kunne opretholdes.

På arbejdsmiljøområdet tegner der sig specielt tre opgaver, hvor et stærkere nordisk samarbejde kan anbefales: Psykisk arbejdsmiljø, en intensiveret fællesnordisk indsats i arbejdet i EU's ekspertkomiteer, hvor man fastsætter grænseværdier m.v. og en gennemgang af erfaringerne med tilsynet på arbejdsmiljøområdet.

Nordisk Institut for Videreuddannelse inden for Arbejdsmiljøområdet (NIVA) besidder en væsentlig kompetence inden for formidling og videreuddannelse af eksperter og praktikere, herunder også tilsynsinspektører, inden for arbejdsmiljø og vil mere tværgående være en værdifuld komponent $\mathrm{i}$ implementeringen af initiativer på området.

Det psykiske arbejdsmiljø trænger til et erkendelsesmæssigt, forskningsmæssigt og politisk løft. Statens rolle i forhold til arbejdsmarkedets parter på dette område og vægtningen af ledelsesretten i forhold til tilsynets påbud i sager om det psykiske arbejdsmiljø varierer i et vist omfang fra det ene nordiske land til det andet. Dette gør psykisk arbejdsmiljø til et oplagt emne for et forsøg på en nordisk harmonise- ring af lovgivningen. Med så relativt snævre egentlige ekspertmiljøer i de enkelte lande vil det herudover være både fagligt og økonomisk rigtigt at opbygge en bedre koordination af aktiviteter og projekter på området. Myndigheder, forskere og organisationer børi et samarbejde prioritere projekter af fælles interesse. Netværker er gode, men vi har i Norden et behov for mere end det.

Arbejdet i EU's ekspertkomiteer har stor praktisk betydning for de krav, grænseværdier m.m. der gennem direktiver m.v. bliver fastlagt på arbejdsmiljøområdet. Norden besidder et betydeligt potentiale af ekspertise spredt på forskellige institutioner og forskningsmiljøer i landene, og der er en betydelig mødeaktivitet på de forskellige fagområder inden for arbejdsmiljøarbejdet. En mere organiseret og målrettet indsats mellem disse netværker og myndighederne i Norden vil kunne styrke vores indflydelse og interessevaretagelse i det løbende arbejde i EU.

Hvad angår tilsynet, tegner der sig tre særlige spørgsmål: Den kvantitative indsats, egenkontrollen som tilsynsmetode samt virkningen på opretholdelsen af kvaliteten og dækningen af tilsynet i lys af den øgede anvendelse af underleverandører, vikarbureauer samt også væksten i uafhængige enkeltmandsvirksomheder. I denne forbindelse er samspillet mellem arbejdstilsynet og andre myndigheder som Skat og Politi væsentlig. En fælles, løbende opdateret nordisk database over særlige problematiske sager såvel som en komparativ gennemgang af situationen på de her anførte tre områder kunne være nyttig. 
Forslag 4: $\quad$ Ministerrådet beslutter en opprioritering af indsatsen vedrørende det psykiske arbejdsmiljø. Muligheden for en egentlig nordisk lovharmonisering på området, som juridisk sidestiller det psykiske arbejdsmiljø med det fysiske undersøges. Under alle omstændigheder udarbejdes et fælles nordisk arbejdsprogram, der sikrer en opsamling af best practices, identificerer og udvikler mere strukturerede samarbejdsformer i Norden på området og engagerer Norden mere vedholdende og proaktivt i samarbejdet i EU på området.

Arbejdsmiljøudvalget under Embedsmandskomiteen for Arbejdsliv (EK-A) udarbejder oplæg til temadrøftelse i Ministerrådet for Arbejdsliv (MR-A) om en styrkelse af Nordens deltagelse i og prægning af arbejdet i EU's ekspertkomiteer på arbejdsmiljøområdet.

Erfaringsudvekslingen mellem ministrene om tilsynet med arbejdsmiljøet understøttes af et uafhængigt udarbejdet oplæg til temadrøftelser med særligt henblik på de tre her fremhævede spørgsmål. 


\section{Ligestilling}

Der er stadig lommer af lavere løn til kvinder. Problemet bliver ikke mindre af tendensen til lavere organisationsdækning og crowding in effekten på den dårligst betalte og dårligst uddannede del af arbejdsmarkedet. Den strukturelle baggrund for dette er naturligvis generel og ikke specifikt rettet mod kvinderne på arbejdsmarkedet. Men det er en faktor, der levetidsforlænger og skærper problemet med forskelsbehandling, og som derfor påkalder sig særlig opmærksomhed. Ikke mindst i sammenhæng med migrationspresset og udfordringen med integrationen på arbejdsmarkedet er der skabt et særligt behov for at sikre, at kvindernes situation ikke ender i en slags kønspolitisk kulturel blindgyde, som også på længere sigt blokerer for ligestilling. Der er også af denne grund behov for igen at se på den positive betydning for ligestillingen, som f.eks. tilstedeværelsen af velbemandede børneinstitutioner har haft for kvindernes position på arbejdsmarkedet. En kritisk kvantitativ og kvalitativ opdatering af institutionerne vil styrke grundlaget for ligestilling på arbejdsmarkedet - ikke mindst for kvinderne blandt flygtninge og indvandrere.

Introduktionen af obligatorisk voksen- og efteruddannelse som foreslået i denne rapport vil kunne bidrage til at mindske det uddannelses- og karrieremæssige efterslæb, som mange kvinder oplever i forhold til deres mandlige kolleger.

Et særligt aspekt af betydning for ligestillingen er den relativt lavere grad af diversitet $i$ erhvervsstrukturen og dermed i uddannelsesbilledet som karakteriserer yderområderne i Norden, først og fremmest Grønland og Færøerne, men også Island. Igen er dette ikke noget, der alene retter sig mod kvindernes situation, men noget, der i praksis vanskeliggør ligestillingen på arbejdsmarkedet.

\section{Forslag 5: $\quad$ Ligestillingsspørgsmålet bør helt tværgående gives prioritet $\mathrm{i}$} samarbejdet om arbejdsliv i Norden. 


\section{Strukturændringer og organisationernes repræsentativitet}

Uanset det forhold, at der er forskelle mellem organisationsprocenterne i fagbevægelserne i de nordiske lande, så er det et fælles træk, at en række faktorer har bidraget til en svækkelse af den høje organisationsprocent, der prægede industrisamfundet $i$ årene med opbygningen af velfærdssamfundene. En meget diversificeret servicesektors fremmarch, væksten i små virksomheder inden for kommunikation, rådgivning m.m. har ført til et ændret billede i forhold til den klassiske struktur på arbejdsmarkedet. Hertil kommer, at der i det mindste $i$ et af de nordiske lande er vokset konkurrerende faglige organisationer frem, som tilbyder et billigere alternativ for medlemmerne, men som ikke dækker det spektrum, som de traditionelle organisationer tilbyder i form af egentlig forhandlingskompetence på overenskomstområdet samt en række services på områder som arbejdsmiljø, efteruddannelser m.m. En øget tendens til anvendelse af vikarbureauer og underleverandører, bl.a. i forbindelse med udenlandske virksomheders skiftende engagementer har også især i visse sektorer som f.eks. byggeriet fragmenteret arbejdsmarkedet. Endelig har indvandringen, både fra EU-lande og udefra, øget udbuddet af kun delvist integreret arbejdskraft specielt i bunden af kvalifikationshierarkiet.

På arbejdsgiversiden har strukturændringerne også påvirket den klassiske situation. Det er i dag en betydelig udfordring at organisere de mange virksomheder i de nye sektorer, hvor kulturen og måske også forholdet mellem ejerne og de ansatte er anderledes end $\mathrm{i}$ industrien. Hertil kommer tendensen til, at de store internationalt arbejdende koncerner ("de magtfulde singler") varetager deres interesser uafhængigt af arbejdsgiverorganisationerne - uanset om de er medlemmer af dem eller ej. Samlet set er der derfor tale om en fælles udfordring for begge parter på arbejdsmarkedet $i$ at fastholde autoriteten og legitimiteten af deres centrale rolle i forhandlingsmodellen. Uanset de naturlige interessemodsætninger, der løbende definerer indholdet i forhandlingerne, eksisterer der således en erkendelse af et fælles ansvar for at opretholde en tilstand på arbejdsmarkedet, hvor det er muligt at lave bindende aftaler der sikrer stabilitet og forudsigelighed, og hvor denne måde at varetage de respektive interesser på også danner grundlag for en betydelig fælles indflydelse på samfundspolitikken mere generelt.

Både på lønmodtagersiden og for arbejdsgivernes vedkommende er der et udbygget nordisk netværk og samarbejde, selvom de egentlige forhandlinger naturligvis foregår mere eller mindre centralt på national basis. Arbejdsgivernes samarbejde har ikke en udadvendt karakter, men foregår uformelt, omend klart struktureret. På lønmodtagersiden er Nordens Faglige Samorganisation udtryk for en mere formaliseret og udadvendt organisationskultur. Det ovenfor beskrevne pres på repræsentativiteten er nok generelt anerkendt som et bekymrende problem på politisk hold, men i overensstemmelse med den grundlæggende enighed om, at det ikke er statens rolle at bestemme over organisationsforholdene på arbejdsmarkedet, er dette en udfordring, organisationerne principielt set selv må tage hånd om. Dog er det væsentligt at erkende, at eksistensen af forhandlingskompetente repræsentative organisationer på arbejdsmarkedet faktisk kan ses som en ressource, der alment og i samspil med staten og lovgivningsmagten i mange sammenhænge muliggør løsninger i Nor- 
den, som ikke er mulige i samfund, hvor tilsvarende forhold ikke gør sig gældende på arbejdsmarkedet.

Der er i praksis en række områder, hvor lovgivning og administration direkte påvirker baggrunden og mulighederne for styrkelsen af organisationernes repræsentativitet, primært på lønmodtagersiden. Skatteregler i relation til A-kasse- og fagforeningskontingent kan nævnes som eksempel herpå. Forskelle af denne art behandles typisk som varianter af grænsehindringer men handler i denne sammenhæng egentlig mere om organiseringshindringer. Det kan naturligvis også i en række henseender ses som et politisk kontroversielt problemfelt. Men i det omfang, vi tager betydningen af at fastholde værdien og funktionsevnen af den nordiske aftalemodel for arbejdsmarkedet alvorligt, må vi også erkende, at der er områder, hvor det fra politisk hold er en meningsfuld forpligtelse at bidrage. $0 \mathrm{~g}$ i det omfang, vi ønsker, at samarbejdet i Norden om arbejdsmarkedet ikke kun skal handle om det fælles arbejdsmarked som sådan, men også om, at det er en fælles udfordring i det nordiske samarbejde at bidrage til kvaliteten af dette, så vil det være meningsfuldt at tage landenes og samarbejdets muligheder for at styrke repræsentativiteten i aftalemodellen op i dialogen mellem regeringerne.

I endnu højere grad end de her påpegede faktorer bidrager teknologiændringer, strukturændringer i erhvervslivet og ikke mindst fremvæksten af nye former for organisering af arbejdslivet til erosionen af organisationernes repræsentativitet. Enkeltpersoner udfører opgaver for virksomheder uden at der etableres et regulært ansættelsesforhold. Hjemmearbejde, ikke mindst IT-opgaver, kommunikation og forskellige former for rådgivning løses på basis af mere eller mindre formaliserede kontrakter, men typisk uden den sikkerhed for disse self employed hvad angår afbrydelse af arbejdsforholdet, pension, barselsorlov, feriepenge og mange andre rettigheder, som ellers er sikret ved regulære ansættelsesforhold, hvor faglige organisationer og udøvelsen af et regulært arbejdsgiveransvar er rammen for beskæftigelsen. Store serviceområder dækkes i stigende grad af et arbejdsliv, der ikke nødvendigvis ligger inden for grænsen af den formelle økonomi, hvilket i sig selv er et alvorligt samfundsproblem. Mange - især de mere ressourcestærke - ser ganske enkelt denne udvikling som noget privat, og noget, man føler harmonerer med et ønske om frihed og selvstændighed. Men realiteten er, at de fleste, der havner i kategorien self employed gør det af nødvendighed på grund af vanskeligheden ved at få et regulært job og ikke som et foretrukket alternativ.

Der er stor spredning mellem den situation en højtuddannet akademiker med specielle kvalifikationer står i og situationen for de fleste andre på dette voksende "daglejermarked". Uden den tryghed, en klassisk organisering giver medlemmerne af en fagforening, vil en voksende gruppe af self employed over tid indebære et pres på det offentliges sociale tryghedssystem, samtidig med, at en fortsat erosion af medlemstallet i fagforeningerne og en mere spredt varetagelse af en organiseret arbejdsgiverrolle svækker de to parters autoritet $i$ udøvelsen af deres fælles ansvar for stabiliteten på arbejdsmarkedet. Alt i alt en udvikling, der vil være i modstrid med de værdier, vi ønsker at værne om på det nordiske arbejdsmarked.

Der er internationalt meget stor opmærksomhed om denne udvikling. ILO lægger med sit store projekt "The Future of Work" 
op til en fokusering på disse spørgsmål som et hovedtema i forbindelse med markeringen af organisationens 100 års jubilæum i 2019, og også OECD lægger betydelige ressourcer i området. Begge organisationer ser gruppen af nordiske lande som en velkommen og væsentlig partner i arbejdet med at finde løsninger på de problemer, fragmenteringen af arbejdslivet indebærer. Også EU-Kommissionen betragter denne udvikling som noget, der yderligere komplicerer bestræbelsen på gennem en bred dialog med de sociale partnere at nå frem til stabile og velordnede tilstande på det europæiske arbejdsmarked.

Fagbevægelsen bygger på organiseringen af lønmodtagere på arbejdspladserne og på at varetage deres interesser gennem kollektive aftaler med arbejdsgiverne. De forskellige variationer af "self employed" passer ikke ind i denne model. Det er en komplicerende faktor, at der også på arbejdsgiverside er en vis uklarhed med hensyn til, hvordan man skal forholde sig til dette fænomen, der flytter erhvervsaktivitet væk fra de veldefinerede strukturer, og som i øvrigt kun vanskeligt flugter med virksomhedernes bestræbelser på at markere deres "Corporate Social Responsibility". Man kunne udtrykke dette som arbejdsgivernes "Organized Social Responsibility”.
Uanset at der nok er en tilbøjelighed til at nye tendenser tiltrækker sig uforholdsmæssig stor opmærksomhed, så er der intet, der tyder på, at fragmenteringen af arbejdsmarkedet vil stoppe. Det er derfor en udfordring for især fagbevægelsen at udvikle nye former for organisering og tilbud til de forskellige varianter af self employed som vil betrygge den enkeltes situation også selvom man ikke er ansat på en arbejdsplads i stil med traditionelle lønmodtagere. I afsøgningen af ideer til udvikling af en sådan hybrid-organisering vil det være relevant bl.a. at se på, hvordan freelance journalister, artister og lignende individuelt udøvende er organiseret. Statens rolle bør være at understøtte organisationernes arbejde med at finde løsninger på denne udfordring, således at man kan sikre en fungerende balance mellem det offentliges sociale system og vilkårene på denne anderledes del af arbejdsmarkedet.

For arbejdsgivernes vedkommende vil der være en tilsvarende udfordring med at udfylde det organisatoriske tomrum, som fragmenteringen i erhvervsstrukturen skaber. Det er væsentligt at understrege, at samfundets overordnede interesse i udviklingen af nye mere adækvate og fleksible organisationsformer i lige så høj grad retter sig mod arbejdsgivernes organisationer som lønmodtagernes.

Forslag 6: $\quad$ Ministrene drøfter på grundlag af forarbejde i EK-A konkrete lovgivningsmæssige, herunder skattemæssige, forhold, der kan hæmme bestræbelsen på at konsolidere arbejdsmarkedsorganisationernes repræsentativitet. EK-A udarbejder i samarbejde med sekretariatet og arbejdsmarkedets parter i Norden et oplæg til en tematisk drøftelse mellem ministrene med det videre formål at nå frem til et katalog med ideer til brug i indsatsen i Norden og internationalt om tilpasning til de krav, som fragmenteringen af arbejdslivet stiller os over for. 


\section{Uddannelse}

Der er almindelig enighed $i$ alle de nordiske lande om, at mere uddannelse er en afgørende del af svaret på udfordringen fra globalisering, digitalisering og teknologiudviklingen i det hele taget. Dette er ikke kun i forhold til industrisamfundets konkurrenceevne, men i lige så høj grad centralt i det servicetunge vidensamfund. Kombinationen af en hurtig teknologiudvikling og en gradvis højere pensionsalder $\emptyset$ ger yderligere behovet for noget nyt på uddannelsesområdet. Hertil kommer det generelle ekstra pres på kapaciteten i uddannelsessystemet, som migrationspresset indebærer. Opretholdelsen af et højt velstandsniveau og et menneskeligt tilfredsstillende arbejdsliv, der forventes at blive længere end i dag, er præmisser, vi stort set tager for givne som en del af "den nordiske model". Men for at de nordiske lande i fremtiden skal kunne fastholde deres position i den globale konkurrence, skal der uddannelsesmæssigt noget andet og mere til end more of the same. Udfordringen er ikke work harder men work smarter.

Det er bestemt ikke nogen ny iagttagelse, at der er brug for en mere ambitiøs indsats på uddannelsesområdet. Der lægges betydelige kræfter i voksen- og efteruddannelse, ofte tæt knyttet til virksomhedernes eller institutionernes behov og styret af disse, men også i form af skabelsen af arbejdstageres rettigheder til efteruddannelse forhandlet mellem parterne på arbejdsmarkedet. Det generelle billede er, at akademikere i kraft af karakteren af deres arbejde involveres mere i efteruddannelse op gennem arbejdslivet end andre grupper, men der er også en tendens til, at faglærte i stigende grad gennemfører uddannelser, der flytter dem op i kompetencehierarkiet.
Problemerne med den store gruppe af unge, der efter afgangen fra folkeskolen ikke kommer videre i uddannelsessystemet, er naturligvis genstand for betydelig opmærksomhed i alle landene. I forbindelse med denne rapport om arbejdslivet i Norden er det ikke formålet at gå i detaljer om de forskellige uddannelsesområder. Men en særlig fokusering på sikringen af, at man gennem en bred indsats helt generelt får skabt et højere "bundniveau" på arbejdsmarkedet, står frem som noget helt essentielt. Dette både af hensyn til, at dette vil indebære et bedre udgangspunkt for også at involvere denne kategori på arbejdsmarkedet i efteruddannelser, og fordi migrationspresset ganske enkelt indebærer, at der ikke findes noget alternativ til en massiv indsats på dette punkt.

For at komme godt ind i fremtiden skal vi uddannelsesmæssigt ud af boksen. Det ville det være en visionær beslutning, hvis de nordiske lande i fællesskab og under medvirken af parterne på arbejdsmarkedet udvikler en model for, hvordan man i praksis kan gennemføre princippet om, at voksen- og efteruddannelse skal være et obligatorisk element $i$ arbejdslivet. Skabelsen af det fælles nordiske arbejdsmarked i 1954 var heller ikke nogen rutinebeslutning. Der vil være mange betænkeligheder, interessekonflikter og ikke mindst store vanskeligheder med fordelingen af omkostninger og rettigheder uanset, hvilke modeller, man forestiller sig for dette. Med hensyn til ambitionsniveauet vil der helt naturligt skulle være tale om en gradvis satsning m.h.t. for eksempel varighed af uddannelsestiltagene. Men noget af denne slags, noget som bekræfter vore samfunds innovationskapacitet, og som kan løfte de nordiske lande ind i en vinderposition i den globale konkurrence, bør forsøges. 
Man kan forestille sig to grundmodeller i forsøget på at virkeliggøre denne vision. Den systemisk mest ambitiøse kunne være et fælles udviklingsprojekt besluttet af Nordisk Ministerråd og med en fællesnordisk styregruppe med deltagelse af arbejdsmarkedets parter, hvor pilotprojekter i de enkelte lande omfattende forskellige dele af arbejdsmarkedet kan bruges til at afprøve gennemførligheden og til at belyse omkostningerne. Det offentlige må nødvendigvis acceptere at se denne satsning som en nødvendig og fremtidsrettet fortsættelse af den investering i uddannelse, som hidtil har været mønstret. Det, at børn og unge skal uddanne sig, og at samfundet har et ansvar for dette, har jo nu i over 100 år ikke været kontroversielt. Arbejdsmarkedets organisationers medvirken vil være essentiel - ikke mindst fordi det er dem, der i overensstemmelse med forhandlingskarakteren af arbejdslivets udvikling vil skulle sikre en balance mellem pligter og rettigheder i et sådant system, såvel som relevansen af indholdet i obligatoriske voksenuddannelser.
Den anden grundmodel vil fremstå mindre systemisk og ambitiøs og vil bygge på en organisk og mindre styret vækst af aftaler mellem parterne, som gradvist vil dække mere og mere af det samlede arbejdsmarked, tilpasset de mange forskellige forhold, der gør sig gældende fra branche til branche osv. Statens rolle i denne model vil være at facilitere og økonomisk tilskynde denne udvikling. Det nordiske samarbejdes rolle i denne model vil være at samle initiativer og aftaler op, sikre umiddelbar erfaringsudveksling og stimulere udbredelsen af best practices.

Uanset hvilken model, der måtte besluttes af regeringerne, vil selve det forhold, at noget sådant sættes i gang i Norden, bidrage til at øge forståelsen for, hvad vi har af potentiale i den innovative forhandlingskultur i "den nordiske model". Lige som de nordiske lande gik forrest i 1954 med skabelsen af et fælles arbejdsmarked, bør vi i dag gå forrest i mødet med fremtidens udfordringer.

Forslag 7: De nordiske regeringer tilslutter sig princippet om indførelsen af obligatorisk voksen- og efteruddannelse for alle på arbejdsmarkederne i Norden og beslutter sammen med arbejdsmarkedets parter iværksættelsen af forsøgsaktiviteter gennem fælles pilotprojekter som her beskrevet i de to grundmodeller for gennemførelsen af princippet.

I forbindelse med denne nødvendige opprioritering af uddannelsen som en mere systematisk og integreret del af arbejdslivet i fremtiden, vil det være vigtigt at samfundet og arbejdsmarkedets parter forholder sig ansvarligt og solidarisk til den kategori af medborgere, der ganske enkelt ikke er i stand til at følge med, og for hvem kravet om opkvalificering mere opfattes som en trussel end som et tilbud. Det er politisk ukorrekt at sige det, men realiteten er, at det er en lige lovlig bekvem eufemisme at lade, som om alle kan uddannes til at udfylde en produktiv og meningsfuld rolle på fremtidens arbejdsmarked. I takt med digitaliseringen, teknologiudviklingen og globaliseringens krav om konkurrencedygtighed må vi være indstillet på, at denne restgruppe med en vis sandsynlighed vil vokse, hvorfor samfundet må indrette sig på at sikre disse medborgere en tryg og anstændig tilværelse. Arbejdsmarkedspolitisk og socialpolitisk er det naturligvis ikke nogen nem sag at definere afgrænsningen af denne kategori. Pointen er imidlertid, at de nemme svar om at "alle kan noget, alle kan lære noget og alle skal have et job” ikke nødvendigvis er hverken realistisk eller særlig menneskevenligt. 


\section{Vestnorden}

Der er reelle geografiske og erhvervsstrukturelle grunde til, at forholdene på arbejdsmarkederne i Færøerne, Island og Grønland adskiller sig markant fra situationen i resten af Norden. Men uddannelsen af de unge og indsatsen mod ungdomsarbejdsløshed er en udfordring, der kendes overalt i Norden. Mange unge tager til andre lande - både i Norden og udenfor - for at gennemgå højere uddannelser, og mange kommer ikke tilbage. Samarbejdet om fjernundervisning på jurauddannelsen mellem Aalborg Universitet og universiteterne i Grønland og Færøerne kan være et eksempel på tiltag, der kan reducere denne tendens.
Den begrænsede diversitet i de relativt små økonomier domineret af fiskerisektoren indebærer, at behovet for jobskabelse på alle niveauer bliver særlig vigtig. Oven i dette betyder den relativt store pendling eller mere eller mindre permanente migration efter jobs i de øvrige nordiske lande (f.eks. arbejdere fra Færøerne i norsk olieindustri eller byggeri), at planlægning eller initiativer vanskeliggøres. Det er ovenfor anført, at erhvervsstrukturen i de vestnordiske økonomier yderligere kan være en faktor, der påvirker ligestillingen.

I forhold til Færøerne, Island og Grønland kan det ikke afvises, at sprogene kan udgøre en hæmsko for en uddannelsesmæssig og arbejdsmarkedsmæssig integration i resten af Norden.

Forslag 8: $\quad$ De særlige udfordringer, der gør sig gældende for jobskabelsen i Vestnorden, gøres til genstand for en særlig undersøgelse udført i samarbejde mellem EK-A og sekretariatet, hvis konklusioner danner grundlag for ministrenes drøftelse og stillingtagen. 



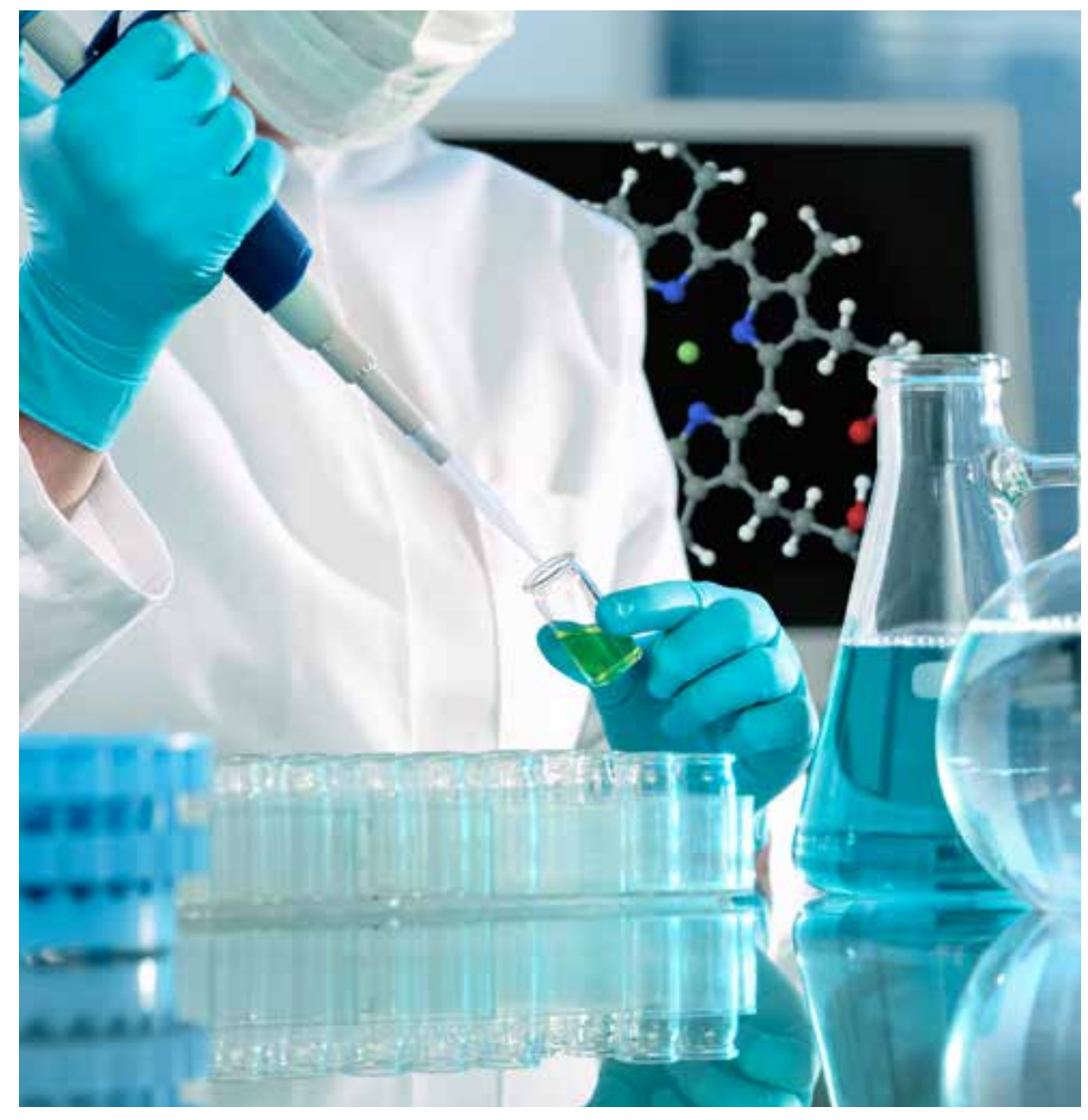




\section{Institutionelle emner}

Det er bemærkelsesværdigt, hvor omfattende og differentieret et net af mere eller mindre formaliserede relationer, der karakteriserer samarbejdet på arbejdslivsområdet i Norden. Det er i det hele taget bemærkelsesværdigt ved samarbejdet mellem de nordiske lande, at dette er noget, der går igen på alle områder, også uden for det samarbejde, der foregår i regi af Nordisk Ministerråd og Nordisk Råd.

På alle niveauer - ministrene, embedsmandskomiteerne, organisationerne på arbejdsmarkedet, de relevante forvaltningsgrene med relation til arbejdsmarkedet og forskere på universiteterne - har man fremhævet erfaringsudvekslingen og den uformelle og direkte form ved sam- arbejdet som noget nær det vigtigste og mest værdifulde. Samtidig kan man spore en vis tendens til, at man anser denne fremhævelse som udtryk for fraværet af et højere politisk ambitionsniveau i samarbejdet. Inden man ser på dette, er det i al fairness værd at notere, at det vidt forgrenede nordiske samarbejde sådan som vi kender det, er noget, man i de fleste regioner i verden ikke har bygget op, og noget, mange misunder os. Det er en kolossal ressource at kunne drøfte problemer og ideer mellem naboer, der i kraft af et vist fællesskab kan forstå hinanden, men hvor der alligevel er tale om visse forskelle, der giver grundlag for en reel og relevant erfaringsopbygning og innovationsoverførsel. 


\section{Ministerrådet for Arbejdsliv (MR-A)}

Det er imidlertid et selvstændigt formål med denne gennemlysning af arbejdslivet i Norden at fremkomme med forslag til en styrkelse af det nordiske samarbejde, hvorfor ministerrådets ambitionsniveau og arbejdsform naturligt påkalder sig en nærmere drøftelse. Det skal her understreges, at Ministerrådet for Arbejdsliv (MR-A) ikke kan forventes at skille sig væsentligt ud fra de øvrige sektormæssige ministerråd $\mathrm{i}$ henseende til de formelle muligheder og begrænsninger i beslutningskompetence.

Det er påfaldende, at man fra alle sider $\mathrm{i}$ det institutionelle billede af samarbejdet giver udtryk for et ønske om, at ministrenes møder i højere grad bliver præget af mere substantielle politiske temaer, drøftelser og beslutninger. Dette ønske er ikke noget nyt, men det virker lidt, som om alle mere eller mindre på forhånd resignerer ud fra en betragtning om, at når det virker urealistisk at forvente sig klare, umiddelbart bindende beslutninger fra ministrene, så er der ikke rigtigt noget at gøre for at forbedre den politiske produktivitet i systemet. I en sammenligning mellem MR-A og de fleste andre sektorers ministerråd må det imidlertid holdes for øje, at en arbejdsministers virkelighed og politiske arbejdsvilkår i høj grad er defineret af samspillet med arbejdsmarkedets organisationer, hvad enten det foregår i formaliserede trepartsforhandlinger eller i løbende konsultationer om bl.a. implementering af EU-direktiver og mange andre spørgsmål. Det er yderligere sådan, at dette samspil i praksis er rettet mod, hvordan man håndterer sager om arbejdslivet i det på gældende land.

Det er derfor en lidt for nem påstand, når man siger, at det, der mangler, ganske enkelt er politisk vilje. Det er en ofte set tilbøjelighed $\mathrm{i}$ internationale organisationer (og egentlig ikke kun dér), at man kompenserer for fraværet af interessant realpolitisk diskussion ved at formalisere og pumpe dagsordenen op til et punkt, hvor f.eks. godkendelsen af referatet fra det foregående møde gøres til noget, der ligner en betydningsfuld beslutning. Også tilbøjeligheden til at fylde dagsordenen op med punkter, der hverken lægger op til diskussion eller beslutning, kan få indkaldelsen til at se betydningsfuld ud, men som i realiteten kommer til at fungere som en tidsrøver, og som virker alt andet end motiverende for ministrenes personlige engagement og investering $i$ en aktiv deltagelse i møderne.

Sådan som både de formelle og realpolitiske generelle vilkår er for samarbejdet $\mathrm{i}$ Nordisk Ministerråd er det derfor ikke relevant at måle et ministerråds produktivitet på forekomsten af bindende beslutninger med umiddelbar virkning i hele Norden. Derimod giver det god mening at måle samarbejdets produktivitet på kvaliteten af diskussionerne direkte mellem ministrene og på de initiativer, de i fællesskab beslutter at igangsætte samt på ministrenes kollektive engagement $\mathrm{i}$ implementeringen af disse. Med fare for at blive misforstået kan det alligevel vanskeligt udtrykkes bedre, end at det gælder om at gøre møderne mellem ministrene til en "god klub" i stedet for en overformaliseret mødemaskine. Vejen til at øge den politiske betydning af MR-A er at gøre deltagelsen i dette samarbejde til en attraktiv, meningsfuld og nødvendig del af ministrenes tidsanvendelse. Det vil i denne forbindelse være nødvendigt overalt i samarbejdet at forholde sig pragmatisk og usentimentalt til sprogproblemet.

Det forudsætter meningsfulde og i fællesskab udarbejdede opspil til ministrene såvel som en vis dristighed hos dem at hæve ambitionsniveauet for samarbejdet. Beslutningen om gennemførelsen af nærværende gennemlysning af arbejdslivet i Norden med henblik på at styrke det nordiske samarbejde og den internationale interessevaretagelse på dette område må ses som udtryk for, at ministrene har taget det første skridt i denne retning. 
Forslag 9: Dagsordenen til ministermøderne opdeles i A-punkter, der forudsættes ikke at give anledning til diskussion, og B-punkter, hvor det forudsættes, at der diskuteres og eventuelt besluttes. Opdelingen foretages i EK-A, hvor embedsmændene på vegne af deres ministre inden møderne afklarer, hvilke punkter, der er enighed om. Der lægges i højere grad end hidtil op til politiske temadrøftelser mellem ministrene på grundlag af oplæg produceret i et bredere samarbejde.

Der er tre væsentlige aktører i tilrettelæggelsen af møderne mellem ministrene: Det pågældende formandsskabslands arbejdsminister, som typisk har formuleret visse prioriteringer i sammenhæng med landets øvrige program for formandsskabet. EK-A, hvor embedsfolk med fokus på faglig/politisk betjening af hver deres minister med talepunkter m.v. som på sin vis styrer substansen i drøftelserne. Ministerrådets sekretariat har traditionelt på arbejdslivsområdet haft en overvejende logistisk og praktisk støttefunktion, men ønsket om en stærkere markering af det tværgående, fællesnordiske perspektiv taler for, at sekretariatet i overensstemmelse med argumentationen fremlagt i rapporten "Nyt Norden" spiller en mere substantiel rolle i forberedelsen af ministermøderne. Der vil således blive behov for en tættere koordination mellem disse tre instanser i sammenhæng med en opprioritering af sekretariatets rolle.

Hertil kommer behovet for en bedre anvendelse i en mere integreret proces rettet mod ministermøderne af arbejdet i de forskellige udvalg under EK-A: Nordisk Arbejdsretsudvalg (NAU), Arbejdsmarkedsudvalget og Arbejdsmiljøudvalget. Også det i denne rapport foreslåede udvalg om migrationspresset må indgå i denne proces. Specielt bør den særlige juridiske ekspertise i NAU bringes i spil som et væsentligt element i den i forslag 12 beskrevne aktivitet rettet mod lovgivningsprocessen i EU.

Forslag 10: $\quad$ Sekretariatet for Nordisk Ministerråd bør udøve en mere substantiel, initierende og koordinerende rolle i forberedelsen af ministermøderne - både for at sikre en bedre sammenhæng og inddragelse af arbejdet i de forskellige udvalg under EK-A og for at styrke den fællesnordiske dimension i ministrenes drøftelser.

En uomgængelig problemstilling i forbindelse med hele tankegangen bag denne gennemlysning vil naturligvis være, at et højere ambitionsniveau for det nordiske samarbejde på arbejdslivsområdet, således som det i overensstemmelse med opdraget kommer til udtryk i denne rapport, nødvendigvis også må indebære øgede ressourcer. Arbejdsministrene kan ikke forventes at levere dette alene. Regeringerne som sådan må forholde sig til nødvendigheden af at skabe balance mellem ambitionen i det nordiske samarbejde og de midler, der stilles til rådighed for det.

Forslag 11: $\quad$ Regeringerne må forholde sig til nødvendigheden af at sikre en tilstrækkelig og stabil finansiering af et mere ambitiøst nordisk samarbejde på arbejdslivsområdet. 


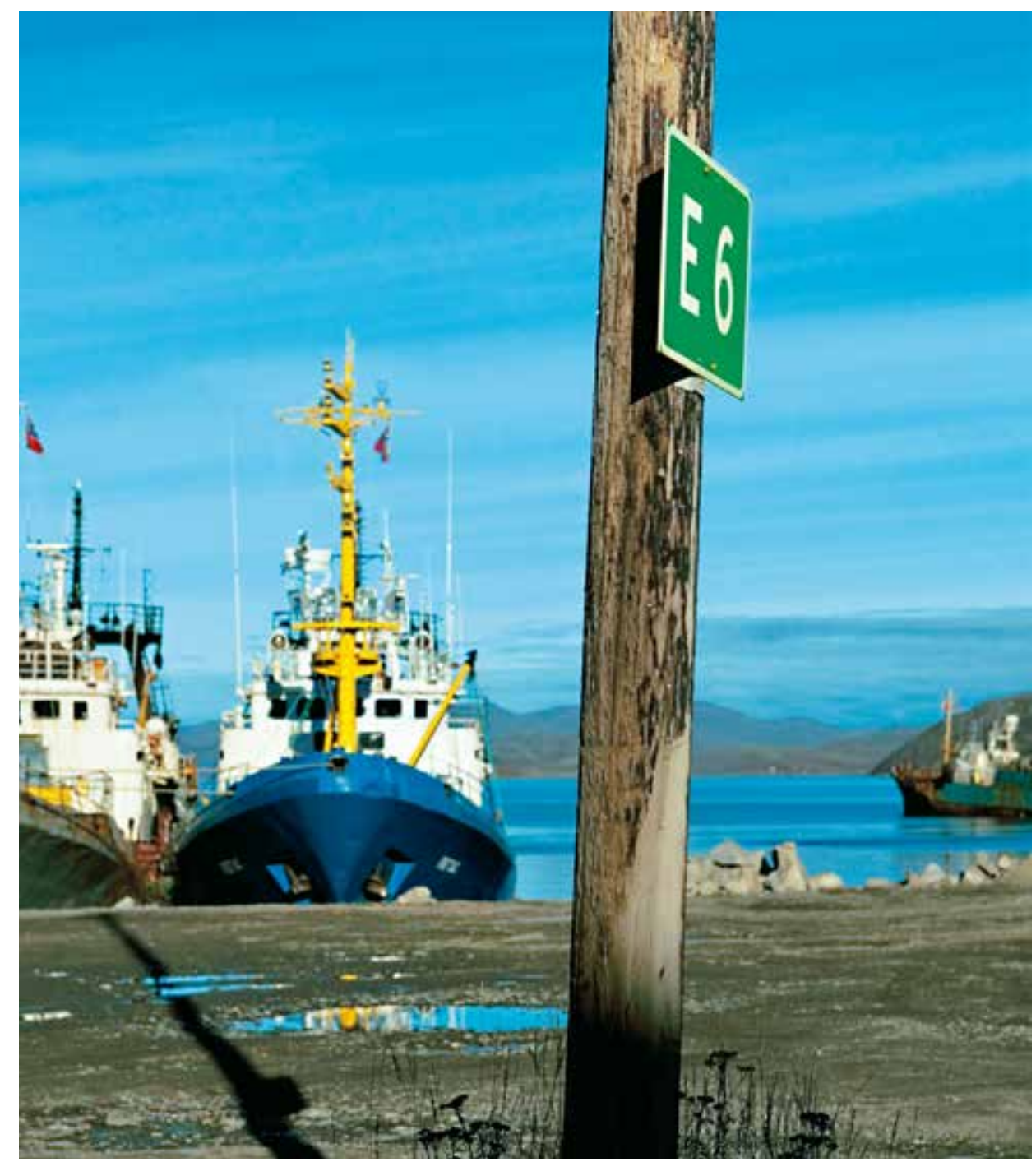




\section{Norden i EU}

\section{Beskrivelse}

Bestræbelsen på gennem en fælles lovgivningsproces at opbygge en arbejdsmarkedspolitik i EU er en velbegrundet og logisk følge af konsolideringen af det indre marked. Virkeliggørelsen af den frie etableringsret for virksomheder er et klart plus for Europas økonomiske udvikling. Sikringen af vandrende arbejdstageres rettigheder samtidig med opretholdelsen af respekten for overenskomster og regler $\mathrm{i}$ øvigt på medlemsstaternes arbejdsmarkeder er en lige så essentiel forudsætning for virkeliggørelsen af et velfungerende indre marked. At ramme en passende balance mellem disse faktorer er ikke kun en teknisk/juridisk udfordring men også en sag, der på flere ledder er præget af klassiske, modsatrettede interesser.

En umiddelbar sammenligning mellem forudsætninger og vilkår for skabelsen af det fælles nordiske arbejdsmarked og det fælles europæiske arbejdsmarked, der ikke mindst efter udvidelsen af EU i 2004 omfatter medlemslande med meget forskellige økonomiske og sociale udgangspunkter, illustrerer både, hvorfor det er kompliceret at skabe en bredt accepteret balance, og hvorfor der i langt de fleste medlemslande er en velbegrundet interesse i opbygningen af en fællesskabsbaseret arbejdsmarkedspolitik.

De nordiske lande adskiller sig fra stort set resten af EU's medlemslande (og for den sags skyld fra resten af verden) ved at have en struktur på arbejdsmarkedet med veldefinerede og repræsentative aktører både på arbejdsgiver- og arbejdstagersiderne, hvor statens rolle er relativt tilbagetrukket, og hvor parternes forhandlede aftaler respekteres. I modsætning til dette er billedet i de andre lande præget af en opsplittet og svag organisationsstruktur på begge sider af arbejdsmarkedet - eller en ubalance i forholdet mellem dem - og en tradition for, at lovgivningsmagten bestemmer ganske mange af de vilkår, der i de nordiske lande fastlægges gennem forhandlinger mellem parterne.

Dette indebærer, at selve det forhold, at man anvender lovgivningsprocessen i EU til at skabe et fælles retsgrundlag for arbejdsmarkedspolitikken, betragtes som en naturlig og velkommen arbejdsform for at sikre rettigheder og definere en vis balance mellem de forskellige modstridende interesser og hensyn, mens denne proces set med nordiske øjne uanset indholdet af det ene eller det andet direktiv grundlæggende må ses som en trussel mod kernen i den model, vi har opbygget. Der er således to lag af spørgsmål at forholde sig til i forholdet mellem "den nordiske model" og lovgivningsprocessen i EU, nemlig statens rolle i forhold til aftalefriheden mellem parterne og de konkrete indholdsmæssige aspekter vedrørende direktiverne og deres implementering. I begge henseender er der behov for, at de nordiske lande i fællesskab engagerer sig mere proaktivt for at varetage vore synspunkter og interesser.

Spørgsmålet om forholdet mellem staten som lovgiver og parternes aftalefrihed er 
andet og mere end et principielt spørgsmål om institutionelle magtforhold. Helt ned i detaljen på en arbejdsplads gør det en reel forskel, om en medarbejder kan få opbakning og bistand om mægling fra sin tillidsmand og fagforening, eller om man vil være henvist til at søge advokatbistand og føre en sag med de negative konsekvenser, dette uundgåeligt vil medføre både for den pågældendes fortsatte ansættelse og for virksomheden. Også for arbejdsgiverne indebærer aftalesystemet væsentlige fordele i form af fredspligt og stabilitet. Lønmodtagernes og arbejdsgivernes fælles ejerskab af overenskomster og eksistensen af et særligt arbejdsretligt system baseret på en respekt for dette skaber grundlag for en tillid, der er forankret på en anden måde, og som i praksis fungerer bedre, end ved at staten har dikteret reglerne.

Arbejdsmarkedspolitik i EU kræver énstemmighed i Ministerrådet. Kommissionen har godt nok sin initiativret, men har ikke samme kompetence på dette område som f.eks. i handelspolitikken eller andre områder. Man er derfor nødt til at manøvrere i en mere spredt og situationsbestemt proces med open coordination. Forordninger, der umiddelbart har virkning i medlemslandene, er meget vanskelige at skabe énstemmighed bag. Direktiver, som indebærer en vis fleksibilitet $\mathrm{i}$, hvordan det enkelte medlemsland transformerer og implementerer det som national ret, er derfor helt naturligt den dominerende juridiske ramme for lovgivningsprocessen i europæisk arbejdsmarkedspolitik. Det er Kommissionens opgave at kontrollere, at medlemslandene i deres implementering af direktiverne holder sig inden for deres formål og substans. I betragtning af de interesser, der knytter sig til hele sagsområdet, og i betragtning af den stykvise karakter af lovgivningen, kan det ikke undre, at der løbende rejses sager ved EU-Domstolen, som i sine kendelser i realiteten er den instans, der ultimativt fastlægger indholdet i EU's politik og retstilstand på arbejdsmarkedsområdet.

Der er således ikke kun tale om, at processen bidrager til at forrykke balancen mellem parternes aftalefrihed og staten som lovgiver, men at domsmagten kommer til at spille en egentlig rolle i defineringen af gældende ret. Dette er ikke enestående for arbejdsmarkedspolitikken i EU, men en konstruktion, der helt bevidst blev skabt for at der kunne både mægles og skæres igennem i den komplicerede proces med den fortløbende integrationsproces, og som generelt har tjent samarbejdet $\mathbf{i}$ Europa godt. Men kontrasten netop på arbejdsmarkedsområdet i forhold til "den nordiske model" er klar.

EU-Domstolen baserer sine afgørelser på traktaterne - inklusive præamblen til Lissabon-traktaten om menneskerettigheder - samt fortolkningen af lovgivningen i form af direktiver og forordninger, og det er helt legitimt, når den lægger vægt på, at afgørelserne skal styrke de grundlæggende principper for udviklingen af samarbejdet i Europa.

EU-Domstolen er imidlertid ikke alene om at afsige kendelser med virkning for arbejdsmarkedet i Europa og i Norden. Norge og Island er, som de andre EØS-lande med deltagelse i EU's indre marked, forpligtet til at følge stort set alle de regler, der vedtages i EU. EØS-landenes opfyldelse af dette krav overvåges af EFTA-sekretariatet som en parallel til Kommissionens rolle i EU. Sager kan indbringes for EFTA-domstolen, som således også fortolker EU-lovgivningen og afsiger endelige kendelser. 
Den tredje domstol, der afsiger kendelser i sager om arbejdsmarkedsforhold, er Den Europæiske Menneskerettighedsdomstol, hvis juridiske grundlag er Den Europæiske Menneskerettighedserklæring, som bl.a. omhandler retten til organisering. Enkeltpersoner kan indbringe en sag for Menneskerettighedsdomstolen efter at de nationale retlige instanser er udtømt.

Alle tre domstole afsiger endelige kendelser og gør dette helt uafhængigt af hinanden. Man kan indvende, at kendelserne godt nok er endelige, men at EU jo altid har muligheden for efterfølgende at ændre på lovgivningen og dermed få det sidste ord. Men en sådan korrigerende finjustering tager under alle omstændigheder ganske lang tid og er ikke nogen enkel sag at føre igennem; alle de modsatrettede interesser kommer naturligt op igen. Den aktuelle proces med en revision af udstationeringsdirektivet er en klar illustration af dette.

I lys af den stykkevise karakter af direktiverne og de meget bredt formulerede principper i traktater og menneskerettig- hedstekster samt den specifikke baggrund for de sager, der kommer op i konsekvens af manglende klarhed i medlemslandenes implementering af direktiver m.v. må det konstateres, at der ikke er tale om en situation, der lever op til, hvordan man ville forvente, at den dømmende myndighed skulle se ud i et velorganiseret demokratisk politisk system. Men af respekt for domstolenes uafhængighed er der ingen, der rejser en debat. Denne rapport indeholder heller ikke forslag til konkrete initiativer fra de nordiske arbejdsministre på dette punkt. Men det er både legitimt og relevant at eksponere denne tingenes tilstand, ikke mindst fordi de nordiske lande med deres lidt forskellige status i forhold til lovgivningsprocessen på arbejdsmarkedsområdet i Europa må efterleve de tre domstoles afgørelser, og fordi disse afgørelser direkte eller indirekte påvirker den særlige balance mellem staten og arbejdsmarkedets parter, der er en afgørende del af kernen i "den nordiske model". 


\section{Hvad kan Norden gøre?}

De nordiske landes regeringer såvel som parterne på arbejdsmarkedet investerer allerede betydelige ressourcer $i$ at følge med i og øve indflydelse på lovgivningsprocessen i EU, både ved arbejdet i NAU og i ministerierne hjemme i hovedstæderne såvel som gennem de udstationerede medarbejdere ved repræsentationerne i Bruxelles. Hovedvægten $\mathrm{i}$ indsatsen synes imidlertid at være lagt på, at det enkelte nordiske land med fokus på de særlige forhold, der kendetegner landets arbejdsmarkedspolitiske situation, forsøger at skabe forståelse for og om muligt en hensyntagen til disse. Det, der bærer legitimiteten i denne form for indflydelsesoptimering, er typisk, at man kan pege på helt specifikke forhold i et forslag, som vil forårsage betydelige konkrete problemer i landets eksisterende situation, uden at disse forhold er essentielle for forslagets formål i øvrigt. Altså en slags teknisk/politisk rådgivning af gensidig interesse.

En sådan individuel ageren kan være velbegrundet bl.a. i lys af nuanceforskelle i, hvordan man i de forskellige nordiske lande implementerer direktiverne, ligesom adgangen til at gøre sine synspunkter gældende i en mere selektiv og netværksbaseret dialog i den komplekse beslutningsstruktur i Kommissionen, Parlamentet og i forhandlingerne i Rådet ofte kan være nemmere at håndtere for landene enkeltvis. Begrænsningen i denne arbejdsform er imidlertid, at der for det meste bliver tale om en reaktiv og også typisk defensiv indsats, og en indsats, der ikke åbner for en mere overordnet og strategisk dialog om principperne i lovgivningen. $\mathrm{Og}$ hovedproblemet for de nordiske lande i lovgivningsprocessen på arbejdsmarkedsområdet i Europa er jo netop at skabe bedre forståelse for grundprincipperne, eller kernen, i "den nordiske model", således at vi ikke med det ene direktiv efter det andet stilles over for større og større udfordringer.

En af de mange samtalepartnere i løbet af tilblivelsen af rapporten sagde om Norden set $i$ en international sammenhæng: "Det er vanskeligt at være anderledes". At løfte opgaven med at skabe forståelse og respekt for kernen i "den nordiske model" kræver en fælles indsats af mere generel og vedholdende karakter. Det gælder i forhold til EU og i forhold til verden udenfor. Det er en pædagogisk udfordring, hvor nuancer og forskelle mellem landene på arbejdsmarkedsområdet naturligvis forklares, men hvor hovedvægten må lægges på at præsentere værdien af et arbejdsmarked, hvor der er tillid til holdbarheden af parternes aftaler, og hvor deres kompromiskompetence i praksis udgør en ressource for samfundet - økonomisk såvel som stabilitetsmæssigt. Kommissionens revitalisering af den sociale dialog i EU udgør et oplagt forum, hvor nordiske arbejdsgivere og faglige organisationer vil kunne bidrage til forståelsen og respekten for "den nordiske model".

I forhold til det mere konkrete arbejds felt i lovgivningsprocessen i EU vil en mere markeret fælles nordisk optræden føje en tungere og mere proaktiv dimension til landenes individuelle indsats. Et enten-eller mellem en organiseret fælles indsats og landenes individuelle arbejde er ikke spørgsmålet. Men en styrkelse af Nordens interessevaretagelse er nødvendig, ikke 
kun for at undgå vedtagelsen af regler, der underminerer funktionsmåden på de nordiske arbejdsmarkeder, men også for at de principper, vi har demonstreret værdien og funktionsdygtigheden af, kan blive tillagt vægt i den videre udformning af politikken i EU.
Der er således både behov for en almindelig synliggørelse - eller branding - af kernen i "den nordiske model" og en målrettet og mere proaktiv fælles nordisk interessevaretagelse både gennem den sociale dialog og i lovgivningsprocessen i EU.

Forslag 12: $\quad$ Arbejdsministrene træffer efter konsultationer med de nordiske arbejdsgiver- og arbejdstagerorganisationer principbeslutning om at organisere en stærkere fælles markering af kernen i den nordiske arbejdsmarkedsmodel $i$ en fortløbende indsats rettet mod at skabe større forståelse og respekt for denne både i den revitaliserede sociale dialog i EU, i det lovforberedende arbejde i Kommissionen og i en stærkere fælles interessevaretagelse i forhandlingsprocessen $i$ Parlamentet og i Rådet efter fremlæggelsen af Kommissionens forslag. 


\section{Norden i verden}

\section{Den Internationale Arbejdsorganisation (ILO)}

Den Internationale Arbejdsorganisation fylder 100 år i 2019. ILO har haft stor betydning globalt gennem det normative arbejde med konventionerne, med afgørelser af tvistigheder i ekspertkomiteen og med projektarbejde med kapacitetsudvikling ikke mindst i udviklingslandene. De nordiske lande har gennem årene spillet en aktiv rolle i ILO, ikke mindst fordi organisationens formål og arbejdsform med direkte deltagelse af arbejdsgiversiden og fagbevægelsen flugter godt med det, der karakteriserer arbejdsmarkedet i de nordiske lande. Som udgangspunkt for et intensiveret samarbejde mellem de nordiske lande og ILO er der allerede et velfungerende samarbejde mellem de nordiske landes diplomatiske repræsentationer ved ILO i Geneve.

Et stort anlagt analysearbejde og omfattende debatter om fremtidens arbejdsliv "Future of Work" er iværksat som et tilløb til jubilæet. En væsentlig del af dette projekt handler om repræsentativiteten af de klassiske organisationsformer på arbejdsmarkedet i lys af bl.a. teknologiændringer, global konkurrence, og sektormæssige strukturforskydninger i erhvervslivet, hvorved der sker en hastig vækst $\mathrm{i}$ self employment eller uformelle enkeltmandsengagementer uden den sikkerhed og klarhed for den enkelte, som er en del af traditionelle ansættelsesforhold. Ikke mindst i udviklingslandene - men i høj grad også i industrilandene - indebærer dette en sløring af grænsen mellem den uformelle og den formelle økonomi og udgør en hæmsko for opbygningen af et regulært af- talebaseret arbejdsmarked, hvor pligter og rettigheder for såvel arbejdsgivere som lønmodtagere er tydeliggjort. I 2017 afholder ILO et panel om de sociale partneres repræsentativitet, hvilket er en illustration af den fundamentale betydning, man tillægger skabelsen og opretholdelsen af velorganiserede arbejdsmarkeder.

ILO ser positivt på de nordiske landes aktive engagement $i$ en dialog om denne udfordring. I lys af den i international sammenligning velfungerende arbejdsmarkedsmodel, vi har i Norden, er der en forventning om, at vi i særlig grad vil kunne bidrage med ideer til "Future of Work"-processen.

Det samme gør sig gældende på statistikområdet, hvor et tættere samarbejde med den nordiske gruppe hilses velkomment.

I diskussionen om "den nordiske models" attraktivitet og mulige anvendelse rundt om i verden er ILO en naturlig platform for præsentation af både aftalefriheden som kernen i modellen og de variationer i øvrigt, der gør sig gældende fra land til land i Norden, og de forudsætninger af bredere samfundspolitisk, historisk og kulturel art, der er sammenhængende forudsætninger for "modellens" eksistens og funktionskraft. Det interessante i forbindelse med et fælles nordisk engagement i denne diskussion vil i høj grad være, hvordan man mere selektivt og tilpasset vil kunne overføre nordiske erfaringer til andre lande, som ser "den nordiske model" som en inspiration. Hvor vanskelig denne diskussion end kan være, vil den være meningsfuld for vores egen selvforståelse og for muligheden for "modellens" bæredygtighed i en globaliseret verden, hvor det er vanskeligt at være anderledes. 


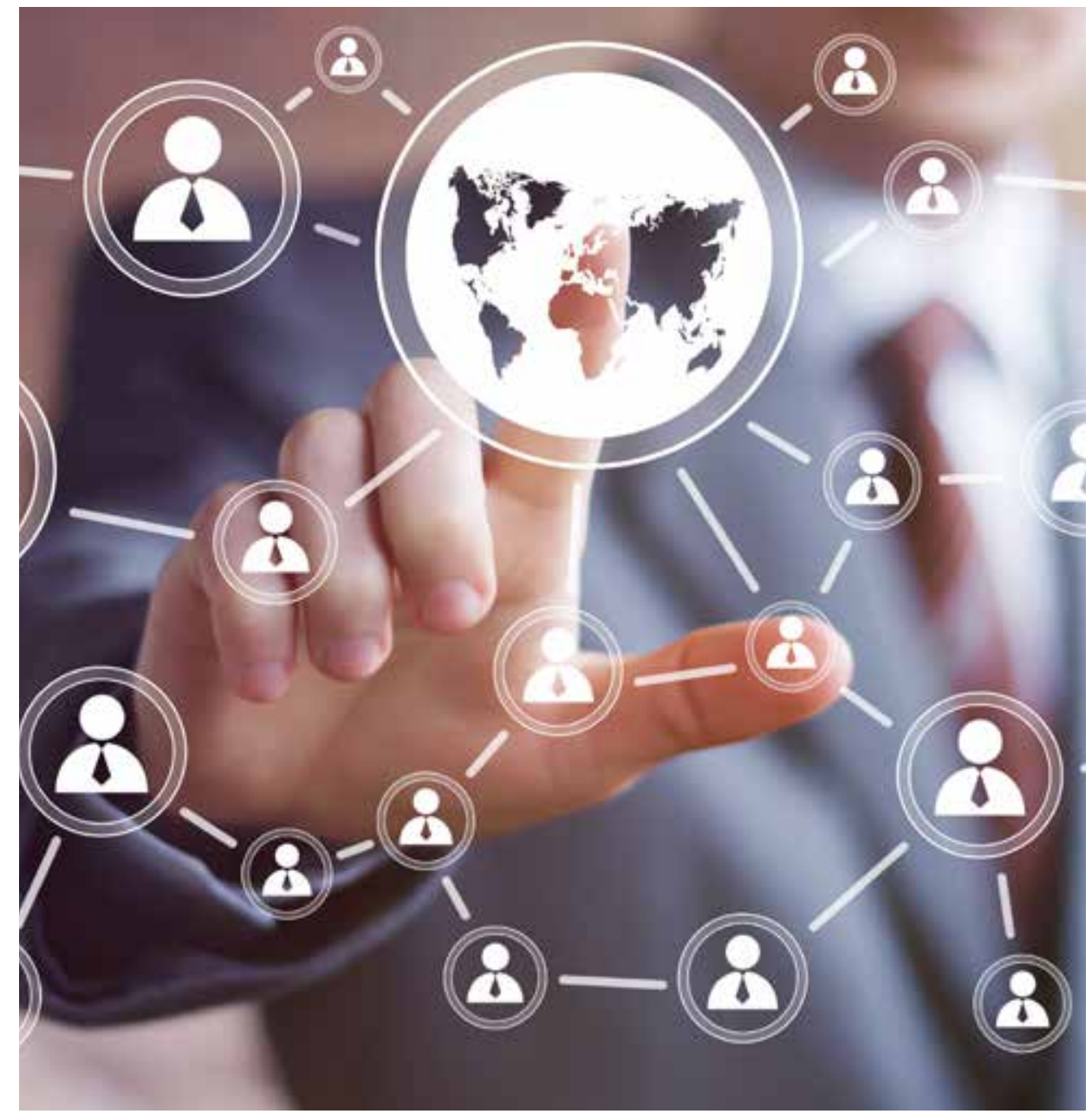

Forslag 13: MR-A intensiverer samarbejdet med ILO i rammen af "Future of Work" projektet, arbejdet med at forbedre arbejdsmarkedsstatistikken internationalt og den generelle dialog om udbredelsen og forståelsen for de grundlæggende principper i "den nordiske model". Dette arbejde gennemføres i videst muligt omfang i et nært samarbejde med såvel arbejdsgivernes som lønmodtagernes nordiske organisationer. 


\section{OECD}

OECD spiller en væsentlig rolle i den løbende internationale diskussion om principperne og karakteren af industrilandenes $ø$ konomiske politik. Organisationen fremstår både som en højt kvalificeret institutionaliseret tænketank og en aktør, som i forbindelse med landeeksaminationerne formulerer kritik og anbefalinger angående medlemslandenes økonomiske politik i bred forstand. I dette arbejde er der en klar anerkendelse af den forskel, der er mellem den amerikanske/angelsaksiske økonomiske samfundsmodel og de nordiske velfærdssamfund med forhandlingsmodellen på arbejdsmarkedet, som således tegner sig som et alternativ i den internationale principielle økonomiske diskussion. Det er også anerkendt, at de nordiske landes økonomiske resultater bidrager til at stimulere interessen for "den nordiske model".

Dette gør naturligvis helt generelt OECD til en væsentlig samarbejdspartner for de nordiske lande i bestræbelsen på at skabe international forståelse for den måde, vore samfund - og ikke mindst arbejdsmarkedet - fungerer på. Men derudover er OECD's analytiske og idéudviklende arbejder på en række områder af direkte interesse for de udfordringer, vi står over for på de nordiske arbejdsmarkeder: Sammenhængen mellem udviklingen på arbejds- markedet og den demografiske udvikling hen mod en ældre befolkningssammensætning, væksten i psykiske problemer i arbejdslivet, fragmenteringen af arbejdslivet (self employment-udfordringen), som OECD har iværksat en systematisk kortlægning af, forbedringen af statistik, hvor OECD hilser et nærmere samarbejde med Norden velkommen, uddannelsesområdet, hvor reformer af voksenuddannelserne tillægges høj prioritet, samt et initiativ med at udbrede nationalregnskabsmodellerne ("Better Life Initiative") til at inddrage faktorer som menneskelig trivsel, social tryghed m.m. i en mere kvalitativ opgørelse end den traditionelle BNP-opgørelse.

Alt dette taler til fordel for, at der i det nordiske samarbejde i OECD investeres ressourcer i et direkte og aktivt engagement på disse områder - både for at facilitere et kvalitativt direkte input til den fælles politikudvikling i Norden, og for at de ideer og synspunkter, der har rod i "den nordiske model", løftes over i den globalt orienterede politikudvikling i OECD. Samarbejdet mellem Norden og OECD både generelt og på disse områder følges op med substantielle temadrøftelser på møderne i MR-A på grundlag af et samarbejde mellem de nordiske landes repræsentationer ved OECD-sekretariatet samt departementerne hjemme og forberedt og koordineret af sekretariatet.

Forslag 14: $\quad$ MR-A beslutter en opprioritering af Nordens samarbejde i OECD, både i dialogen om grundprincipper i den økonomiske politik og på de mange væsentlige arbejdsmarkedspolitisk relevante områder, der her er antydet. I betragtning af de tværgående aspekter af disse problemfelter koordineres opspillet til de opfølgende temadrøftelser i MR-A af sekretariatet. 



\section{norden}

\section{Nordisk Ministerråd}

Ved Stranden 18

1061 København K

www.norden.org

\section{Arbejdsliv i Norden - Udfordringer og forslag}

Uanset en række forskelle fra land til land i Norden i henseende til struktur og politik på arbejdsmarkedsområdet i bred forstand, så er der en kerne af fælles arbejdsformer, normer og værdier, som tilsammen definerer karakteren af arbejdslivet og arbejdsmarkedspolitikken i de nordiske lande, som gør det meningsfuldt at tale om "den nordiske model”, og som på væsentlige punkter skiller sig ud fra forholdene på arbejdsmarkedet i de fleste andre lande - både i Europa og i resten af verden.

Udfordringerne og mulighederne for at identificere nye ideer, der kan styrke samarbejdet i Norden på arbejdslivsområdet kan opdeles i fire kategorier:

- Substantielle, fællesnordiske emner

- Institutionelle emner i det nordiske samarbejde

- Det nordiske arbejdsmarked

- EU. Norden i verden. 